\title{
RNF43 Gene Mutation
}

National Cancer Institute

\section{Source}

National Cancer Institute. RNF43 Gene Mutation. NCI Thesaurus. Code C141252.

A change in the nucleotide sequence of the RNF43 gene. 